\title{
Survival Rate, Growth and Chemical Content of Dendronereis pinnaticirris (Polychaeta, Nereidae) in Maintenance with Different Feeds and Substrates
}

\author{
Eko Setio Wibowo ${ }^{1 *}$, Edy Yuwono2, Purnama Sukardi³, Asrul Sahri Siregar ${ }^{3}$ \\ ${ }^{1}$ Faculty of Biology, Jenderal Soedirman University \\ J. dr. Soeparno No.63 Purwokerto 53122, Indonesia \\ 2Faculty of Biology, National University \\ Jl. Sawo Manila, Pejaten Pasar Minggu Jakarta Selatan, Indonesia \\ ${ }^{3}$ Faculty of Fisheries and Marine, Jenderal Soedirman University \\ Jl. dr. Soeparno kompleks GOR Soesilo Sudarman Purwokerto, Indonesia \\ Email: tio_eko@yahoo.co.id
}

\begin{abstract}
The worm Dendronereis pinnaticirris is used as feed of shrimp broodstock in a hatchery, mainly because of its availability in the local market, and its nutritional content required for improving gonad maturation and post larvae production. The important economic value of the worm and the increasing demand for feed in shrimp hatcheries have led to an intense exploitation that deplete its population and the sustainability of the whole estuarine ecosystem. The study, which represents the starting point of large-scale production of the polychaete worm by culture in the artificial system, shall be undertaken. Accordingly, a production study using $D$. pinnaticirris juvenile was carried out under controlled conditions fed with two different feed (feed contains mainly plant protein and animal protein, respectively), and kept in three different substrates (substrate consists of mud and $8.78 \%, 37.34 \%$, $39.17 \%$ sand, respectively). The treatments were arranged according to randomized completely block design in 8 (eight) replicates. The survival rate, body weight increment and growth, oxygen consumption, proximate body chemical, and fatty acid contents were measured. The results showed that growth and oxygen consumption was significantly influenced by a substrate and feed type $(P<0.05)$. Worms on the mud substrate with $39.17 \%$ sand, and feed containing mainly vegetable protein showed the highest oxygen consumption. Survival rate and chemical body content were not significantly influenced by the type of substrate and feed $(P<0.05)$. The protein content of the worm was $32.02-43.81 \%$, while fat content was $2.41-9.89 \%$. Twenty different fatty acids were identified in the worm of all treatment groups.
\end{abstract}

Keywords: Dendroneris pinnnaticirris, fatty acids, growth, oxygen consumption, protein content

\section{Introduction}

Nereid worm Dendronereis pinnaticirris is an invertebrate from the Familia of Nereidae, Classis Polychaeta which live in the estuarin ecosystem as benthic organism but also actively swim in waters during reproduction (Wallace et al., 1991). Sandy soil is a common substrate inhabited by nereid worms including Nereis diversicolor and N. virens, however there are species that live in rocks like $N$. pelagica (Yuwono, 1992). In Indonesia, for example in Java and Sumatra, the worm is derived from its natural habitat in the brackish water area.

Polychaeta including the worm $D$. pinnaticirris can be used as feed of Penaeid shrimp broodstock, because its nutritional content is required to improve the quality of gamete cell and viability of shrimp larvae. $D$. pinnaticirris contains essential amino acids which are dominated by chemoatractant for shrimp and also contains unsaturated fatty acids, especially arachidonic acid (Yuwono, 2005). N. diversicolor that is maintained in an integrated aquaculture with recirculation system contain high quality fatty acids especially ARA, EPA and DHA (Bischoff et al., 2009). Polychaeta also contains reproductive hormones such as prostaglandin E2 (Meunpol et al., 2005). Furthermore, Meunpol et al. (2007) showed that polychaetes Perinereis sp. producing progesterone (P4) and 17-alpha hydroxyprogesterone (17 $\alpha$-OHP4) which have an effect on vitellogenesis and maturity of shrimp gametes .

Utilization of worm D. pinnaticirris as shrimp feed is not only due to its nutritional content, but also because it is easily obtained from the community around the hatchery, therefore it has an important economic value. These animals also play an important ecological role in coastal ecosystems as deposit feeders (Jumars et al., 2015). Polychaeta able to ingestion and defication of sediment rapidly, so that the worm contributes to the regulation of the 
carbon cycle, nitrogen and sulfur. Polychaeta is also able to maintain the stability of sediments that affect the sustainability of the brackish water ecosystem balance (Snelgrove, 1997).

The high economic value of the worm has caused intensive exploitation in its habitat. In the long term, intensive exploitation might threaten $D$. pinnaticirris population and results in the damage of overall brackish water ecosystem. This condition requires efforts to control such exploitation by conducting cultivation of worm $D$. pinaticirris to supply aquaculture demand, thus reducing the dependence on nature. The cultivation of worm $D$. pinaticirris can be a promising business opportunity, therefore research on the production of worm $D$. pinaticirris that became the initial step of the development of mass cultivation has been undertaken.

The results of previous studies indicate that $D$. pinaticirris worms cultivated on substrate enriched with finely grained bran grow better than those cultivated on substrates enriched with faeces of quail (Yuwono et al., 2000). D. pinaticirris maintained on a 63-250 $\mu \mathrm{m}$ diameter soil substrate showed better survival and growth than those maintained on a 250$500 \mu \mathrm{m}$ soil substrate (Mustofa et al., 2012). Feed also affects the survival and growth of marine worms, as reported by (Rasidi and Patria, 2012) that feed made from broiler chicken intestinal flour enhances the survival and growth of Nereis sp.

In order to complete the scientific information for the development of worm culture, a research has been conducted using juvenile of $D$. pinnaticirris obtained from mature worms spawned in the lanoratory. The mature worm was collected from its natural habitat. The study aims to determine the survival, growth, metabolism and chemical content of the worm $D$. Pinaticirris grown in sandy mud substrate and fed with animal and vegetable protein.

\section{Materials and Methods}

Juvenile worms $D$. pinaticirris were taken from laboratoriy at Faculty of Fisheries and Marine Science and Technology, Unsoed, aged 5-6 months, 0.01$0.19 \mathrm{~g}$ in wet body weight, and number of segments was 38-131. Sandy mud substrate and seawater used for the experimental animal breeding media was obtained from Brebes and Cilacap brakish water, and the feed used was fish feed containing vegetable and animal protein.

The experimental animal was acclimated for two weeks in a plastic box sized $(10 \times 8.5 \times 4) \mathrm{cm}^{3}$ containing sandy mud substrate and seawater with a salinity of 15 ppt. Each container contains 3 individual juvenile $D$. pinnaticirris. Prior to use in the experiment the substrate was sieved with a $0.02 \mathrm{~mm}$ strainer, dried in an oven at $90^{\circ} \mathrm{C}$ for $2 \times 24 \mathrm{~h}$ so that the pathogen organisms perish. The experimental medium within teh boxes was aerated to maintain sufficient dissolved oxygen.

The experimental worm and the feed were weighed with an analytic scale (Ohaus) with accuracy of $0.001 \mathrm{~g}$. The increment of posterior segment was counted by observing under a stereo microscope at 10X magnification. The medium temperature was measured by the Celsius thermometer, while the $\mathrm{pH}$ was measured with a universal $\mathrm{pH}$ paper. Medium salinity was measured by hand refractometer (Atago) and was moditored during the experiment. The study was conducted experimentally, with 6 (six) different treatments consist of: (1) SAPN: treatment with type A substrate $(8.78 \%$ sand content) and feed containing vegetable protein; (2) SAPH: treatment with type A substrate (8.78\% sand content) and feed containing animal protein;; (3) SBPN: treatment with type B substrate (39.17\% sand content) and feed containing vegetable protein; (4) SBPH: treatment with type B substrate (39.17\% sand content) and feed containing animal protein; (5) SCPN: treatment with type $\mathrm{C}$ substrate $(37,34 \%$ sand content) and feed feed containing vegetable protein; (6) SCPH: treatment with type C substrate $(37,34 \%$ sand content) and feed containing animal protein. The treatments were arranged in accordance with Randomized Completely Block Design in 8 replicates.

Survival rate and growth parameters that include weight gain and the number of posterior segment increment were calculated according to Hariyadi and Yuwono (1998): SR $=(\mathrm{Nt} / \mathrm{No}) \times 100 \%$ where SR was survival rate; Nt was the number of experimental animals at the end of the study and NO was the number of experimental animals at beginning of the study. WG $=\mathrm{Bt}$ - Bo where WG was weight gain Bt: wet weight of experimental animal at the end of the study, Bo: wet weight of experimental animal at the beginning of the study. NSI = St - SO where SI was the number of segment increment; St was the number of experimental animal segment at the end of the study, so: number of experimental animal segment at the beginning of the study. Specific growth rate was determined according to Chang et al. (2006): SG = ((In Wt - In Wo) / t) x 100\% where SGR: Specific Growth Rate; Wt: worm wet weight at the end of the study (g), WO: worm wet weight at the beginning of the study (g), t: duration of the study (days). Specific growth rate were also determined by calculating the number of segment at the beginning and at the end of the study, ie: SGR = ((In St - In So) / t) x 100\%; where SGR: Specific Growth Rate (\%), St: number of worm segment at the end of the study, SO: number of worm segment at the beginning of the study, t: duration of study (days). 
Oxygen consumption as a metabolic rate parameter is measured at the start of exposure and the end of the study. Measurement of oxygen consumption was performed with Fry's (1971) respirometer in Brougher et al. (2005). The oxygen consumption apparatus consists of two tubes; tube I and tube II were $0.5 \mathrm{~L}$ and $10 \mathrm{~L}$ in volume, respectively. The tubes were aerated and equipped with electrical pump. The measurement accuracy was $0.01 \mathrm{ppm}$ and $0.0001 \mathrm{mg}^{-1} \cdot \mathrm{g}^{-1} \cdot \mathrm{h}^{-1}$.

The initial dissolved oxygen was calculated by the formula according to APHA (2005). The oxygen consumption $\left(\mathrm{mg}^{-1} \cdot \mathrm{g}^{-1} \cdot \mathrm{h}^{-1}\right)$ of the worm was measured using the Fry (1971) method in Brougher et al. (2005): KO2 $=[\{($ DOae - DOtp) - DOtae $\} / \mathrm{KA}] /[\mathrm{N} \mathrm{x}$ $\mathrm{Bi} 3 / 4 \mathrm{xh}$ ] where $\mathrm{KO} 2$ was oxygen consumption (mg$\left.{ }^{1} \cdot \mathrm{g}^{-1} \cdot \mathrm{h}^{-1}\right)$ DOae was dissolved oxygen of medium in aerated tube (mg. $\left.\mathrm{L}^{-1}\right)$, DOtp was dissolved oxygen of medium in treatment tube (mg. $\mathrm{L}^{-1}$ ),, DOtae: dissolved oxygen of medium in tube without aeration (mg.L-1); N was number of the worm; Bi: wet weight of the worm (g), h was the duration of the measurement of oxygen consumption (hr), KA was pump water flow velocity (L.h-1).

The body chemical content of the experimental animals was measured by the Kjeldahl method through proximate analysis (AOAC, 1990). Measurement of fatty acid parameters was done at the beginning and at the end of the study. Measurement of fatty acid content was done by Gas Liquid Chromathography (GLC). Fatty acid levels were calculated by the formula according to McNair and Bonelli (1988): Fatty acid levels (\%) $=[($ Lc / Ls) / Ls $]$ x [(Cs x V) / b]; Lc: sample area, Ls: standard area, Cs: standard concentration, $\mathrm{V}$ : final volume, B: sample weight.

The data obtained was analyzed statistically using two-way analysis (factorial). The treatment was significantly different if $P<0.05$. If the results of the analysis show significant differences, the analysis continues with the Tukey test for the smallest significant difference $P<0.05$. The analysis was performed using software MINITAB 16.

\section{Results and Discussion}

The results showed that the type of substrate and feed did not affect the survival rate $(P>0.05)$. Survival rate of all treatments was $100 \%$. These results indicate that the feed and the type of substrate used in the study are excellent for supporting the life of the worm. These results are in accordance with that of previously reproted by Batista et al. (2003). Who achieved high survival rate in cultivating $N$. diversicolor fed with sea bream dry food
(SBDF) and dried feed of vegetable protein (tetramin). The treatments did not significantly affect $(P>0.05)$ worm survival rate. Results of the recent experiment also confirm the result of study performed by Costa et al. (2000) where N. diversicolor fed with different feed showed a high rate of survival, ie $78 \%-100 \%$. The feed used in recent study perfectly supported the life of the worm $D$. pinnaticirris since the worm could consume the feed of carnivores, herbivores, suspensivores, or detritivores (Nielsen et al., 1995; Riisgárd, 1991 in Batista et al., 2003). Another nereid worm, Nereis diversicolor, able to digest various food ingredients from live foods such as micro and macrozoobenthos and diatoms, organic matter including litter (Costa et al., 2006) and also the feed type of deposit feeders; and the undigested sediment will be excreted in the form of faeces (Siregar, 2008). Therefore, according to Heliskov and Holmer (2001) the polychaete nereid worm plays an important role in the decomposition of organic matter and nutrient circulation in the sediments.

The high survival rate in each treatment in this study shows that the worm can live well on different types of substrate. The results of this study ware in accordance with that of Mustofa et al. (2012), they found that the survival rate of $D$. pinnaticirris cultivated in the substrate with the size of $63-500 \mu \mathrm{m}$ and the thickness of $10 \mathrm{~cm}$ was 92.5-100\%. According to Junardi (2001) Polychaeta live in sanddominated substrate as well as in mud and clay substrate. The distribution of polychaetes is correlated with the substrate type and the worms generally live in soft and sandy substrates. Junardi (2001) further states that polychaeta utilizes the substrate as a living place and as foodstuff, especially those species suspension filter feeder. Filter feeder polychaetes spend most of their life in sanddominated substrates, whereas deposit as well as subsurface deposit feeder live in mud and clay substrates.

The weight gain of $D$. pinnaticirris significantly affected by substrate and feed type $(P<0.05)$, but it did not affected by the interaction between substrate and feed type (Table 1.). Analysis variance showed that experimental animals kept in substrate $A$ (sand $8.78 \%$ ) and fed with feed contain animal protein had the highest body weight gain. This result was in accordance with that of Costa (1999) in which $N$. diversicolor maintained in sandy substrate (500-250 $\mu \mathrm{m}$ in diameter) showed higher body weight than maintained on mud substrate (12.5-63 $\mu \mathrm{m}$ in diameter). Mustofa et al. (2012) also reported that sand substrate of $63-250 \mu \mathrm{m}$ in diameter with a thickness of $10 \mathrm{~cm}$ provided a better growth in $D$. pinnaticirris than those maintained in substrates of 250 to $500 \mu \mathrm{m}$ in diameter. This phenomenon showed that deposit-eating biota in general likes fine- 
grained subtrates, because it can utilize the organic material contained in the substrate as food (Nybakken, 1988).

D. pinnaticirris fed with feed with its protein component mainly animal protein showed the highest body weight gain. The feed containing mainly animal protein proved to be more advantageous for the worm growth than feed containing mainly vegetable protein. According to Millamena et al. (2002) animal raw materials are superior to vegetable raw materials because they contain amino acids methionin and lysin, which are indispensable for growth. The efficiency of animal feed absorption is generally higher than vegetable feed (Yuwono, 2008) and has been proven by Yuwono et al. (2000) that compost wich contain animal protein as a culture medium resulted in better growth rates compared to vegetable protein composts. Batista et al. (2003) also reported a similar phenomenon, in $N$. diversicolor fed fish feed contains animal protein resulted in a relatively higher weight gain compared to those that contain vegetable protein.

The type of substrate and feed showed a significant effect on the increment of number of $D$. pinnaticirris segments (Table 2.). The increment of the number of segment was significantly affected by substrate type and feeding with different protein content $(P<0.05)$, but it did not significantly affected by the interaction between substrate and feed type $(P>0,05)$. The worms maintained in the substrate containing $8.78 \%$ sand showed the highest increment of the number of segments. This result is in accordance with that of Costa (1999) which shows that the addition of setae on $N$. diversicolor maintained on sand substrate is relatively higher than that maintained on mud substrate. $D$. pinaticirris may be better preserved on substrate with low sand proportions, as Barnes (1987) suggests that sandy mud substrate is more suitable for animals living in burrows and only out at certain times for feeding usually during night.

The worms $D$. pinaticirris fed on animal protein have the highest increment of number of segments. This phenomenon confirms the results of Yuwono et al. (2002) suggesting that feed with animal protein content (Brachionus) fed to young worms produces higher number of segment compared to that fed vegetable protein (Spirullina and Chlorella). Animal protein is more complete in its essential amino acid content, whereas vegetable protein lacks one or more essential amino acids that inhibit protein synthesis and restricts the use of other amino acids and consequently affects growth (Campbell et al., 2004).

The specific growth rates of $D$. pinnaticirris calculated by weight gain parameters (Table 3.) and posterior segment growth parameters (Table 5.) were significantly different between treatments. Substrate type and feed type had significant effect $(P<0.05)$ on specific growth rate, but not so with interaction between substrate type and feed type. The substrate type A (sand $8.78 \%$ ) yielded the highest specific growth rate compared to substrate $\mathrm{C}$ (sand $37,34 \%$ ) and substrate $B$ (sand $39,17 \%$ ). This phenomenon is coressponding with the results of Costa (1999) study on $N$. diversicolor maintained with sand substrate (500-250 $\mu \mathrm{m})$ and sludge $(125-63 \mu \mathrm{m})$ which showed length growth rates for sand and sludge, 0.97 and $0.84 \mathrm{~mm}^{\text {day }}{ }^{-1}$, respectively, and the worms achieved commercial size in the market within 72 days with length reached $7 \mathrm{~cm}$ ( $70 \%$ of initial size).

The results of this study also showed that the $D$. pinaticirris fed with feed mainly contain animal protein resulted in the highest specific growth rate (Table 3.). This is presumably due to feed containing animal protein has more advantage for the growth tan that contain mainly vegetable protein. According to Hariyadi et al. (2000) vegetable food is more difficult to digest than animal feed because it contains cellulose. Difficulty in digestion decreases energy allocation for growth. This result is in accordance with that of Costa et al. (2000) where $N$. diversicolor fed with animal protein granule for post larvae shrimp showed higher specific growth rates than those fed with vegetable protein. Batista et al. (2003) reported that $N$. diversicolor fed with dried animal-protein dried foods for S. auratus showed higher specific growth rates than those fed vegetable-protein containing feed for ornamental fish, i.e. $7.88 \% . \mathrm{d}^{-1}$ and $7.78 \% . d$ 1. Nielsen et al. (1995) reproted that $N$. diversicolor fed shrimp feed showed a specific growth rate twice as high as that fed algae.

\section{Oxygen consumption}

The parameter for metabolism in this study is the rate of oxygen consumption. The experimental results showed that the type of substrate and feed type significantly affected $(P<0.05)$ the rate of oxygen consumption of $D$. pinnaticirris (Table 4;), but the interaction between substrate type and feed type $(P>0.05)$ did not so. Worms maintained in a substrate with a sand content of $39.17 \%$ and fed vegetable protein feed showed the highest oxygen consumption.

The worm is influenced by environmental conditions, i.e. those kept in substrate with higher sand content shows higher oxygen consumption, whereas those kept in substrate with lower sand content show lower oxygen consumption. This phenomenon suggests that the worm $D$. pinaticirris is an oxyconformer organism, i.e. the animal whose oxygen consumption rate adjusts to the availability of 
Table 1. Body weight gain (g) of worms $D$. pinaticirris maintained with different substrate and feed. The figures followed by different letters in the same column are significantly different $(P<0.05)$.

\begin{tabular}{ccccc}
\hline Treatment & Initial Weight & Final Weight & Weight Growth Range & Average+ SD \\
\hline SAPN & 0,0621 & 0,2925 & $0.1233-0.3233$ & $0.2304 \pm 0.0636^{\mathrm{ab}}$ \\
SAPH & 0,0429 & 0,3033 & $0.2033-0.3500$ & $0.2604 \pm 0.0443^{\mathrm{a}}$ \\
SBPN & 0,0558 & 0,1254 & $0.0033-0.1200$ & $0.0696 \pm 0.0393^{\mathrm{d}}$ \\
SBPH & 0,0495 & 0,1883 & $0.1000-0.2000$ & $0.1388 \pm 0.0377^{\mathrm{c}}$ \\
SCPN & 0,0683 & 0,2788 & $0.1400-0.2600$ & $0.2021 \pm 0.0470^{\mathrm{b}}$ \\
SCPH & 0,0550 & 0,3108 & $0.1867-0.2933$ & $0.2558 \pm 0.0430^{\mathrm{ab}}$ \\
\hline
\end{tabular}

Table 2. Increment of the number of worm segments of $D$. pinaticirris maintained with different substrate and feed. The figures followed by different letters on the same column are significantly different $(P<0.05)$.

\begin{tabular}{ccccc}
\hline Treatment & Initial Segment Count & Final Segment Count & Range Number of Segment & Average + SD \\
\hline SAPN & 94,5000 & 133,9583 & $19.0000-52.6667$ & $39.4583 \pm 12.5153^{\mathrm{abc}}$ \\
SAPH & 80,5833 & 138,0000 & $46.6667-72.6667$ & $57.4167 \pm 7.5441^{\mathrm{a}}$ \\
SBPN & 96,2083 & 118,2500 & $7.6667-46.0000$ & $22.0417 \pm 12.3795^{\mathrm{c}}$ \\
SBPH & 84,4583 & 126,6250 & $26.6667-58.3333$ & $42.1667 \pm 15.0248^{\mathrm{ab}}$ \\
SCPN & 95,7083 & 125,0417 & $13.6667-44.6667$ & $29.3333 \pm 12.62155^{\mathrm{bc}}$ \\
SCPH & 87,7917 & 130,9583 & $31.3333-66.0000$ & $43.1667 \pm 11.7527 \mathrm{ab}$ \\
\hline
\end{tabular}

Table 3. Specific growth rates based on body weight parameters (\%) of worm $D$. pinaticirris maintained with different substrate and feed. The numbers followed by different letters on the same column are significantly different $(P<0.05)$.

\begin{tabular}{ccc}
\hline Treatment & Range & Average + SD \\
\hline SAPN & $0.0162-0.0348$ & $0.0266 \pm 0.0057^{\mathrm{ab}}$ \\
SAPH & $0.0206-0.0541$ & $0.0362 \pm 0.0115^{\mathrm{a}}$ \\
SBPN & $0.0004-0.0290$ & $0.0159 \pm 0.0089^{\mathrm{b}}$ \\
SBPH & $0.0134-0.0400$ & $0.0250 \pm 0.0100^{\mathrm{ab}}$ \\
SCPN & $0.0202-0.0330$ & $0.0241 \pm 0.0047^{\mathrm{ab}}$ \\
SCPH & $0.0215-0.0475$ & $0.0313 \pm 0.0070^{\mathrm{a}}$ \\
\hline
\end{tabular}

dissolved oxygen in its external environment (Moyes and Schulte, 2008). Substrate with higher sand content has higher dissolved oxygen content than substrate with lower sand content. According to Junardi (2001) the finer the substrate grain, the lower the substrate oxygen because there is more limited space between the substrate grains. The results of this study confirm that of Hardewig et al. (1991); at Sipudusus nudus living in intertidal areas that are regularly exposed to low oxygen conditions capable of responding to hypoxia by decreasing oxygen consumption. Suadicani et al. (1991) also reported that Polychaeta Cirinformia tentaculata able to adapt and survive on temporary hypoxia. Under hypoxia, these animals slowly change from aerobic metabolism to anaerobic metabolism, with the accumulation of alanine and succinate, resulting in low levels of oxygen consumption. The ability to perform anaerobic and aerobic metabolism for energy production enabling this animal to adapt to extremely low oxygen supply conditions (hypoxia). According to Connell and Miller (1995) to compensate for the low dissolved oxygen, some benthic organisms form a high concentration of pigment respiration in body fluids. These respiratory pigments consist of proteins and non-protein components, for example those in polycheta in the form of hemeythrin and chlorocruoin contained in body fluids (Yuwono, 2008).

High consumption of oxygen is one of the high figures of the body's metabolism process in digesting vegetable protein, because vegetable protein has more fiber than animal protein feed. According to Darmadi et al. (2003) the activity of animal metabolism can not be separated from the food consumed that acts as a source of energy. Furthermore, according to Ranjhan (1993) fibrous foods will cause the increase of energy needed in the digestive process, so that energy that can be used to increase body tissue, is expended for the process of digesting fibrous feed.

The higher metabolism in an animal's cell leads to an increased need for oxygen followed by increased oxygen consumption by the animal (Hochachka, 1991). According to Cook et al. (2000); Zimmermann and Kunzmann (2001) oxygen consumption is influenced by changes in the ability of digestibility to food. Oxygen consumption is also influenced by internal factors; namely type, size, reproduction status and daily activities; and external factors such as temperature, salinity and dissolved oxygen content in the environment (Suadicani et al., 1991). Oxyconformer animal such as $D$. pinnaticirris is apparently able to decrease the rate of metabolism when exposed to an environment with low soluble oxygen content such as on a substrate with a low sand proportion. 


\section{Chemical content of the body}

The result of the proximate analysis of the $D$. pinaticirris worm body at the end of the study obtained the highest protein content to the lowest in the treatment of SBPN, SAPH, SCPH, SBPH, SAPN and SCPN, while the fat content of the highest in treatment of SCPH, SAPN, SAPH, SBPH, SBPN and The lowest SCPN (Table 5.). The type of substrate and feed does not affect the protein content and body fat $(P>0.05)$. This result is in consistent with Mustofa et al. (2012) who reported that $D$. pinnaticirris maintained with different substrate particle sizes yielded no different protein retention.

D. pinnaticirris protein content ranged from 32.02 to $43.81 \%$, while the fat content ranged from 2.41 to $9.89 \%$, lower than the protein and fat content of Nereis sp. from nature, that obtained by Rachmad and Yuwono (2000), namely $52.26 \%$ protein and $29.83 \%$ fat. The content of $D$. pinnaticirris protein is also slightly lower tan that of $N$. virens, which is 62.64\% (Yuwono, 2005); polychaeta Perinereis sp. 64,87\%; Marphysa sp. 50,90\% (Meunpol et al., 2005). The highest fat content in $D$. pinnaticirris is higher than the fat content of $N$. diversicolor, which is only 19.3\% (Luis \& Pasos, 1985). This fat content is also higher compared to that of $N$. diversicolor fed different feeds, which ranges from 7.9-20\% (Costa et al., 2000).

The body protein content in the treatment with vegetable diet was lower tahn feed protein (46,99\%), while that with animal protein was higher than feed protein (34,17\%). The content of protein and body fat was strongly influenced by nutritional composition of the feed, but in the treatments have not demonstrated differences in body protein levels. According Yuwono (2008) animal protein generally have better quality than vegetable protein. Protein in the feed will be absorbed and used to build or repair damaged body cells, and very efficient for energy (Lovell, 1989).

Table 4. The rate of oxygen consumption $\left(\mathrm{mg}^{-1} \cdot \mathrm{g}^{-1} \cdot \mathrm{h}^{-1}\right)$ of $D$. pinaticirris maintained with different substrate and feed. The figures followed by different letters on the same column are significantly different $(P<0.05)$.

\begin{tabular}{ccc}
\hline Treatment & Range & Average + SD \\
\hline SAPN & $0.0025-0.0084$ & $0.0060 \pm 0.0022^{\mathrm{abc}}$ \\
SAPH & $0.0067-0.0110$ & $0.0090 \pm 0.0014^{\mathrm{a}}$ \\
SBPN & $0.0011-0.0070$ & $0.0035 \pm 0.0019^{\mathrm{c}}$ \\
SBPH & $0.0038-0.0106$ & $0.0070 \pm 0.0030^{\mathrm{ab}}$ \\
SCPN & $0.0021-0.0077$ & $0.0046 \pm 0.0024^{\mathrm{bc}}$ \\
SCPH & $0.0044-0.0114$ & $0.0068 \pm 0.0023 \mathrm{abc}$ \\
\hline
\end{tabular}

D. pinnaticirris, fed with vegetable protein, had higher body fat content than feed fat content (3.47\%) except in SCPN treatment, whereas in D. pinaticirris worms fed with animal protein the body fat content is higher of feed fat content (4.5\%). Body fat content is strongly influenced by nutritional composition of feed. This result was consistent with that of Luis and Passos (1995) which indicate that food composition is the critical factor in determining the $N$. diversicolor fatty acid composition.

\section{Fatty acid content composition}

The results of qualitative analysis indicate that the worms $D$. pinaticirris in all treatments contained 20 types of fatty acids. The fatty acids consist of 9 types of saturated fatty acids (SAFAs), namely lauric acid (C12: 0), myristic acid (C14: 0), pentadecanoic acid (C 15: 0), palmitate (C16: 0), hepatodecanoic acid C17: 0), stearic acid (C18: 0), heneicosanoic acid (C21: 0), behenat acid (C22: 0), trichosanoic acid (C23: 0). Monointoleic acid (16: 1), elaidic acid (C18: 1, n-9t) acidic acid (C18: 1, n-9c). Polyric acid (C18: $3 n 6)$, linoleic acid (C18: $3 n 6)$, eicosedienic acid (C20: 2), eicosentrienaat acid), docosadienoic acid (C22: 2), eicosapentanoate / EPA (C20: 5n3), and docosahexaenoic acid / DHA (C22: 6n3) (Table 6).

The fatty acid content of SAPN treatment consists of 20 species, SAPH 17 types, SBPN 19 species, 16 species SBPH, 18 species SCPN and 17 species SCPH. These fatty acids are divided into three types: SAFA, MUFA and PUFA (Table 7.). SAFA content in each treatment is relatively the same, this condition according to Sukarsa (2004) caused of the fatty acid group SAFA is the basic component of the fat forming system in living things. While the high content of unsaturated fatty acids might be caused of these fatty acids are more easily metabolized compared with saturated fatty acids.

The composition of fatty acid content of each treatment was relatively similar, ie palmitic (C 16: 0$)$, EPA (C 20: 5n-3), stearic (C 18:0), elaidic (C18:1n9t), oleic (C18:1n9c), Linoleic (C18:3n3) and small amounts of myristic acid (C14:0), palmitoleic acid acid (C16:1), docosahexaenoic acid (DHA) (C22: 6n3). This result was similar to that of Costa et al. (2000) which derives the majority of $N$. diversicolor fatty acids in all treatments of C 16: 0, C 18: 1n-9, C 18: 1n-7, C 18: 2n-6 and C 20: 5n-3. A small number of C 16: 1n-7, C 18: 0, C 18: 3n-3, C20: $2 n-6$ and C 20: $4 n-6$. The fatty acid composition obtained in accordance with Yuwono's research (2005) in the form of myristic acid, palmitic acid, palmitoleic acid, stearic acid, oleic acid, linoleic acid, linolenic acid, and EPA. The high content of palmitic acid and stearic acid is also suitable with the research of Dorgham et al. (2015) in P. cultrifera worms from the 
Table 5. Proksimat body (\%) worm D. pinaticirris maintained with different substrate and feed

\begin{tabular}{cccccccc}
\hline \multirow{2}{*}{ Sample } & $\begin{array}{c}\text { Water } \\
\%\end{array}$ & $\begin{array}{c}\text { Dry Weight } \\
\%\end{array}$ & Protein & Fat & Fiber & Ash & $\begin{array}{c}\text { Ingredients Without Nitrogen Extract } \\
\text { (NFE) }\end{array}$ \\
\cline { 6 - 8 } & & & & & & \multicolumn{3}{c}{ \% Dry Weight } \\
\hline SAPN & 17.31 & 82.69 & 36.18 & 7.51 & 0.73 & 5.11 & 50.49 \\
SAPH & 15.06 & 84.95 & 39.40 & 5.92 & 0.28 & 8.73 & 45.68 \\
SBPN & 12.01 & 87.99 & 42.91 & 3.89 & 4.76 & 1.75 & 46.70 \\
SBPH & 12.03 & 87.98 & 39.14 & 5.79 & 9.94 & 6.09 & 39.04 \\
SCPN & 31.17 & 68.83 & 32.85 & 2.63 & 7.08 & 8.46 & 48.68 \\
SCPH & 8.33 & 91.67 & 39.67 & 9.66 & 7.68 & 1.28 & 40.88 \\
\hline
\end{tabular}

Table 6. The composition of fatty acid body worm D. pinaticirris maintained with different substrate and feed

\begin{tabular}{|c|c|c|c|c|c|c|}
\hline \multirow{2}{*}{$\begin{array}{l}\text { Parameter } \\
(\% \mathrm{w} / \mathrm{w})\end{array}$} & \multicolumn{6}{|c|}{ Treatment } \\
\hline & SAPN & SAPH & SBPN & SBPH & SCPN & $\mathrm{SCPH}$ \\
\hline Fat Content & 5.54 & 4.54 & 4.17 & 6.65 & 5.91 & 7.14 \\
\hline \multicolumn{7}{|l|}{ Fatty Acid } \\
\hline Lauric Acid, C12:0 & 0.01 & 0 & 0.02 & 0 & 0 & 0 \\
\hline Myristic acid C14:0 & 1.38 & 1.67 & 0.98 & 0.36 & 0.86 & 0.7 \\
\hline Pentadecanoic Acid C15:0 & 0.37 & 0.47 & 0.3 & 0.2 & 0.33 & 0.2 \\
\hline Palmitic acid C16:0 & 10.09 & 12.38 & 8.27 & 4.65 & 8.14 & 6.3 \\
\hline Palmitoleic Acid, C16:1 & 1.1 & 1.32 & 0.91 & 0.43 & 0.9 & 0.59 \\
\hline Heptadecanoic Acid, C17:0 & 2.59 & 0 & 2.37 & 1.63 & 2.4 & 1.55 \\
\hline Stearic Acid, C18:0 & 3.78 & 4.48 & 3.22 & 2.36 & 3.49 & 2.35 \\
\hline Elaidic Acid, C18:1n9t & 2.45 & 2.98 & 1.74 & 0.86 & 1.67 & 1.36 \\
\hline Oleic Acid, C18:1n9c & 3.77 & 4.35 & 3.36 & 0.86 & 1.67 & 1.36 \\
\hline Linoleic Acid, C18:3n3 & 3.28 & 3.33 & 2.59 & 1.92 & 2.84 & 2.01 \\
\hline g-Linolenic Acid, C18:3n6 & 0.04 & 0 & 0 & 0 & 0 & 0 \\
\hline Heneicosanoic Acid, C21:0 & 0.57 & 0.06 & 0.05 & 0.04 & 0.05 & 0.03 \\
\hline Cis-11,14-Eicosedienoic Acid, C20:2 & 1.36 & 1.39 & 0.92 & 0.5 & 0.87 & 0.65 \\
\hline Behenic Acid, C22:0 & 0.75 & 0.85 & 0.55 & 0.33 & 0.61 & 0.37 \\
\hline Cis-11,14,17-Eicosetrienoic Acid, C20:3n3 & 0.32 & 0.37 & 0.25 & 0 & 0.26 & 0.25 \\
\hline Arachidonic Acid, C20:4n6 (AA) & 2.96 & 3.4 & 1.84 & 2.07 & 2.67 & 2.18 \\
\hline Tricosanoic Acid, C23:0 & 0.22 & 0.27 & 0.16 & 0.13 & 0.24 & 0.13 \\
\hline Cis-13,16-Docosadienoic Acid, C22:2 & 0.05 & 0.04 & 0.02 & 0 & 0.05 & 0 \\
\hline Cis-5,8,11,14,17-Eicosapentaenoic Acid, C20:5n3 (EPA) & 6.56 & 6.73 & 3.48 & 4.36 & 5.22 & 3.27 \\
\hline Cis-4,7,10,13,16,19-Docosahexaenoic Acid, C22:6n3 (DHA) & 1.84 & 2.14 & 0.96 & 1.1 & 1.39 & 1.31 \\
\hline
\end{tabular}

Table 7. Group of fatty acids body worm $D$. pinaticirris maintained with different substrate and feed

\begin{tabular}{ccccccc}
\hline \multirow{2}{*}{ Group of Fatty Acid } & \multicolumn{9}{c}{ Treatment } \\
\cline { 2 - 7 } & SAPN & SAPH & SBPN & SBPH & SCPN & SCPH \\
\hline SAFA & 9 & 7 & 9 & 8 & 8 & 8 \\
MUFA & 3 & 3 & 3 & 3 & 3 & 3 \\
PUFA & 8 & 7 & 7 & 5 & 7 & 6 \\
\hline
\end{tabular}

Mediterranean Sea. Likewise, according to Palmer et al. (2014), which states that palmitate and stearate acids are commonly found in many types of Polychaeta.

Fatty acid composition obtained in recent study is in accordance with that revealed by Yuwono (2005) in the form of myristic acid, palmitic acid, palmitoleic acid, stearic acid, oleic acid, linoleic acid, linolenic acid and EPA. The study also showed a DHA content ranging from $0.96-2.14 \% \mathrm{w} / \mathrm{w}$. According to Costa et al. (2000) fatty acid composition in $N$. diversicolor are unsaturated fats that reflect the fatty acid composition of the feed and demonstrate the ability to biosynthesize some fatty acids such as $C 20$ : 5n-3 (EPA) and C 22: 6n-3 (DHA). Furthermore Costa 
et al. (2000) showed that polychaeta $N$. diversicolor fed Iow EPA and DHA content contained a higher amount of DHA than those contained in their diet. When worms are fed high DHA (dry feed for sea bream or shrimp larvae), its DHA profile is lower than that contained in the feed. The results also showed that D. Pinnaticirris, which was maintained on substrates with smaller sand content, had relatively higher AA, EPA, and DHA contents. These results are in accordance with that reported by Meunpol et al. (2005), they shows that Polychaeta Perinereis sp. living in the sand have a lower proportion of AA: EPA: DHA, which is $6.40 \%$ : $3.94 \%$ : $0.54 \%$ compared to Polychaeta Marphysa sp who lives in mud: $7.78 \%$ : 7.52\%: 1, 34\%.

\section{Conclusion}

D. pinaticirris could live on different substrate type with vegetable and animal feed type, with 100\% survival. Animal feed and substrate type with lower sand content $(8.78 \%)$ could provide higher growth of worm $D$. pinnaticirris than vegetable and substrate types with high sand content (37.34\% n 39.17\%). Metabolic rate of worm $D$. pinaticirris was higher when maintained with vegetable feed and substrate with high sand content. Worm is oxiconeformer organisms. Body composition (protein, fat, fiber, ash and NFE) worms ware relatively same that on maintenance in different substrates. The composition of the fatty acid content of the worm $D$. pinaticirris body fed with vegetable was more complete than that fed the animal feed kept with the same substrate type. Worms fed on animals and kept on substrate types with low sand content indicate higher EPA and DHA content.

\section{References}

American Public Health Association (APHA). 2005. Standard Methods for the Examination of Water and Waste Water 12 th ed. American Public Health Association Inc., New York.

Association of Official Analitycal Chemists (AOAC). 1990. Official Methods of Analysis, 12th Edition. Washington, D. C: Association of Official Analytical Chemists. $1141 \mathrm{p}$.

Barnes, R.D. 1987. Invertebrate Zoologi. 5th Edition. CBS Collage Publishing, New York.

Batista, F.M., Costa, P.F.E., Ramos, A., Passos, A.M., PFerreira, P.P. \& Da Fonseca, L.C. 2003. Production of the Ragworm Nereis diversicolor (O. F. Múller, 1776), Fed with a Diet for Gilthead
Seabream Sparus auratus L., 1758; Survival, Growth, Feed Utilization and Oogenesis. Bol. Inst. Esp. Oceanogr., 19(1-4): 447-451.

Bischoff, A. A., Fink, P. \& Waller, U. 2009. The fatty acid composition of Nereis diversicolor cultured in an integrated recirculated system: Possible implications for aquaculture. Aquacul. 296: 271-276. doi: 10.1016/j.aquaculture.2009.09. 002 .

Brougher, D.S., Douglass, L.W. \& Soares Jr., J.H. 2005. Comperative Oxygen Consumption and Metabolism of Striped Bass Morone saxatilis and its Hybrid M. chrysop $q \times$ M. saxatilis $\delta$. J. World Aquacul. Soc., 36(4): 521-529. doi: 10.1111/j.1749-7345.2005.tb00400.x

Campbell, N.A., Reece, J.B. \& Mitchell, L.G. 2004. Biologi Edisi V Jilid III. Terjemahan oleh Wasmen Manalu. Erlangga, Jakarta.

Chang, Q., Liang, M.Q., Wang, J.L., Chen, S.Q., Zhang, X.M. \& Liu, X.D. 2006. Influence of Larval Cofeeding with Live and Inert Diets on Weaning the Tongue Sole Cynoglossus semilaevis. Aquacul. Nut., 12: 135-139. doi: 10.1111/j.1365-2095. $2006.00393 x$

Connell, D. W.\& Miller, G.J. 1995. Kimia dan Ekotoksikologi Pencemaran. Terjemahan oleh Koestoer, Y dan Sehati. 1995. UI Press, Jakarta.

Cook, J.T., McNiven, M.A. \& Sutterlin, A.M. 2000. Effect of Food Deprivation on Oxygen Consumption and Body Composition of GrowthEnhanced Transgenic Atlantic Salmon (Salmo salar). Aquacul., 188: 47-63. doi: 10.1016/S00 44-8486(00)00333-1

Costa, F.E.P. 1999. Reproduction and Growth in Captivity of the Polychaete Nereis diversicolor (O. F. Múller, 1776), using Two Different Kinds of Sediment: Preliminary assays. Bol. Inst. Esp. Oceanogr., 15(1-4): 351-355.

Costa, F.E.P., Narciso, L. \& Cancela da Fonseca, L. 2000. Growth, Survival and Fatty Acid Profile of Nereis Diversicolor (O. F. Müller, 1776) Fed on Six Different Diets. Bull. Mar. Sci., 67(1): 337343.

Costa, F.E.P., Oliveira, R.F. \& Cancela da Fonseca, L. 2006. Feeding Ecology of Nereis diversicolor (O.F. Müller) (Annelida, Polychaeta) on Estuarine and Lagoon Environments in the Southwest Coast of Portugal. Pan-Am. J. Aquat. Sci. 1(2): 114-126. 
Hardewig, I., Addink, A.D.F., Griesharber, M.K., Portne, H.O. \& Thillart, G.V.D. 1991. Matabolic Rate at Different Oxygen Levels Determined by Direct and Indirect Calorimetry in the Oxyconformer Sipunculu nudus. J. Exp. Biol., 157:143-160.

Hariyadi, B., \& Yuwono, E. 1998. Penelitian Pendahuluan Kelulusan Hidup dan Pertumbuhan Juvenil Cacing Lur (Nereis sp.) Yang Di Pelihara Dalam Media Salinitas Berbeda. Biosfera 11: 17.

Hariyadi, B., Susilo, U. \& Rachmawati, F.N. 2000. Efisiensi Formula Pakan dan Korelasinya terhadap Kandungan Protein-Lipid Tubuh Ikan Nila Gift (Oreochromis sp.). Seminar Hasil Penelitian Due-Like.

Heliskov, A.C. \& Holmer, M. 2001. Effect of Benthic Fauna on Organic Matter Mineralization in FishFarm Sediment: Importance of Size and Abudance. J. Mar. Sci., 58:427-434. doi: 10. 1006/jmsc.2000.102

Hochachka, P.W. 1991. Design of Energy Metabolism In Prosser, C.D (Editor). Environmental and Metabolic Animal Physiology: comparative animal Physiology, $4^{\text {th }}$ edition, Wiley-Liss. Inc New york pp: 18-23.

Jumars, PA, Dorgan, K.M., \& Lindsay, S.M. 2015, Diet of Worms Emended: An Update of Polychaete Feeding Guilds, Annu. Rev.f Mar. Sci., 7:497520. doi: 10.1146/annurev-marine-010814020007

Junardi. 2001. Keanekaragaman, Pola Penyebaran dan Ciri-ciri Substrat Polikaeta (Filum: Annelida) di Perairan Pantai Timur Lampung Selatan. Tesis Program Pascasarjana IPB, Bogor. (Not Published).

Lovell, T. 1989. Nutrition and feeding of Fish. Van Nostrand reinhold. New York.

Luis, O.J. \& Passos, A.M., 1995. Seasonal changes in lipid content and composition of the polychaete Nereis (Hediste) diversicolor. Comp. Biochem. Physiol. 111: 579-586. doi: 10.101 6/03050491(95)00029-8

McNair, H.M. \& Bonelli, E.J. 1988. Dasar Kromatografi Gas. Diterjemahkan oleh Kosasih Padmawinata. Penerbit ITB, Bandung.

Meunpol, O., Duangjai, E. \& Yoonpun, R. 2005. Determination of Prostaglandin E2 (PGE2) in polychaetes (Perinereis sp.) and its effect on
Penaeus monodon oocyte development in vitro. Proceedings of Larvi'05-Fish \& Shellfish Larviculture Symposium European Aquaculture Society. Special Publication, Belgium, P.6.

Meunpol, 0., Meejing, P. \& Piyatiratitivorakul, S. 2005. Maturation diet based on fatty acid content for male Penaeus monodon (Fabricius) broodstock. Aquacu. Res.36: 1216-1225. doi: 10.1111/j.1365-2109.2005.0 134 2. X

Meunpol, O., lam-Pai, S., Suthikrai, W. \& Piyatiratitivorakul, S. 2007. Identification of progesterone and 17a-hydroxyprogesterone in polychaetes (Perinereis sp.) and the effects of hormone extracts on penaeid oocyte development in vitro. Aquacul., 270: 285-292. doi: 10.1016/j.aquaculture.2007.05.031

Millamena, O. M., Coloso, R.M., \& Pascual, F.P. 2002. Nutrition in Tropical Aquaculture. Aquaculture Departement Southeast Asian Fisheries Development Center. Tighuan, Iloilo: Phillippines.

Moyes, C.D., P.M. Schulte. 2008. Principles of Animal Physiology. $2^{\text {nd }}$ ed. Benjamin Cumming, 1301 Sansome St., San Francisco.

Mustofa, A.G., Harris, E., Supriyono, E. \& Jusadi, D. 2012. Pengunaan Substrat Pasir Untuk Budidaya Cacing Poliket Dendronereis pinnaticirris. J. Akuakul. Indo., 11(2): 118-123.

Nielsen, A.M., Eriksen, N.T., Iversen, J.J.L., \& Riisgárd, H.U. 1995. Feeding, Growth and Respiration in the Polychaetes Nereis diversicolor (facultative filter-feeder) and $N$. virens (omnivorous) - a comparative study. Mar. Ecol. Prog. Ser., 125: 149. doi: 10.3354/meps125149

Nybakken, J.W. 1988. Biologi Laut Suatu Pendekatan Ekologis. Terjemahan oleh Eidman, M., et al.. Gramedia, Jakarta.

Palmer, P.J., Wang, S., Houlihan, A. \& Brock, I. 2014. Nutritional Status of a Nereidid Polychaete Cultured in Sand Filters of Mariculture Wastewater. Aquacul. Nut., 20(6): 675-691. doi: 10.1111/anu.12129

Rachmad, B. \& Yuwono, E. 2000. Pertumbuhan dan Laju Makan serta Efisiensi Protein pada Post Larva Udang Windu yang Diberi Pakan Mengandung Tepung Cacing Lur. Makalah Seminar Nasional Bologi XVI, ITB, Bandung.

Ranjhan, S.K. 1993. Animal Nutrition and Feeding Practices. Vikas Publishing House PVT LTD. India 
Rasidi \& Patria, M.P. 2012. Pertumbuhan Dan Sintasan Cacing Laut Nereis sp. (Polychaeta, Annelida) Yang Diberi Jenis Pakan Berbeda. J. Ris. Akuakul. 7(3): 447-464. doi: 10.15578 /jra.7.3.2012.447-464

Siregar, A.S. 2008. Ekologi Cacing Lur (Dendronereis: Polychaeta) di Area Pertambakan. Makalah Pelatihan Pembenihan Welur, Dendronereis (Nereidae, Polychaeta, Annelida). Universitas Jenderal Soedirman Purwokerto.

Snelgrove, P.V.R., 1997. The Importance of Marine Sediment Biodiversity in Ecosystem Processes, Ambio 26 (8): 578-583.

Suadicani, S.O., Costa, V.C.I. \& Bicudo, J.E.P.W. 1991. Relationship between Oxygen Consumption and Body Size of the Amphinomid Polychaete Eurythoe Complanata. Presented at the VI Annual Meeting of the Federação de Sociedades de Biologia Experimental, Caxambu, MG.

Sukarsa, D.R. 2004. Studi Aktivitas Asam Lemak Omega-3 Ikan Laut Pada Mencit Sebagai Model Hewan Percobaan. Bul.Teknolog. Hasil Perikan. $7(1)$ : 68-79.

Wallace, R. A., Sanders, G.P. \& Ferl, R.J. 1991. Biology: The Science of Life, $3^{\text {rd }}$ Edition, Harper Collins Publishers Inc, New York. pp:669.
Yuwono, E. 1992. Inhibition of Breeding and reserval of senescene by experimental Endocrine manipulation in Nereid Polychaetes. Ph.D. Thesis. University of Newcastle Upon Tyne, England, The U. K.

Yuwono, E. 2005. Kebutuhan Nutrisi Crustacea dan Potensi Cacing Lur (Nereis sp., Polychaeta) Untuk Pakan Udang. J. Pembangunan Pedesaan, 5(1):42-49.

Yuwono, E. 2008. Fisiologi Hewan. Fakultas Biologi. Universitas Jenderal Soedirman, Purwokerto.

Yuwono, E., Haryadi, B., Susilo, U., Siregar, A.S. \& Sugiharto. 2002. Fertilisasi Serta Pemeliharaan Larva dan Juvenil Sebagai Upaya Pengembangan Teknik Budidaya Cacing Lur. Biosfera, 9: 1-8.

Yuwono, E., Siregar, A.S., Haryadi, B. \& Sugiharto. 2000. Kelulusan Hidup dan Pertumbuhan Cacing Lur Dendronereis pinnaticirris (Polychaeta, Nereidae) Yang Di Pelihara pada Substrat dan Padat Penebaran Berbeda. Makalah Seminar Nasional ITS. Surabaya.

Zimmermann, C. \& Kunzmann, A. 2001. Baseline Respiration and Spontaneous Activity of Sluggish Marine Tropical Fishes of the Family Scorpaenidae. Mar. Ecol. Prog. Ser., 219:229239. doi: 10.3354/meps219229. 